\section{INTRODUCTION TO ALGOL}

\section{Introduction to Algol Programming}

By Torgill Ekman and Carl-Erik Fröberg. Second edition. Pp. 172. (Lund: Studentlitteratur; London: Oxford University Press, 1967.) 35s. net.

THIs is an extremely good book and remains one of the best published even four years after its original publication in Sweden. Perhaps the most remarkable feature is the way in which the authors have packed such a comprehensive account into a mere 172 pages. This includes a historical introduction, a recapitulation of some of the jargon of compilation of higher level languages, a good set of exercises, and even some suggestions for the future of the language. However, in the last context, the recent publication of the ALGOL 68 report shows that development has gone much further towards implementation of block structures than was anticipated by the authors.

It is always possible, with the introduction of a subject like ALGOL, to criticize the order of presentation. It is desirable to bring ideas forward to give a foel for the language as, for example, has been done on page 8. But occasionally this goes too far and would confuse the beginner, as in the example at the bottom of page 16 , where a real procedure is brought forward nine chapters. It seems odd to delay the description of the goto statement until the seventh chapter, long after the introduction of the if statement. Similarly, the very powerful for statement first appears in chapter 10, although it is so valuable in illustrating the manipulation of arrays. It would be of practical value to indicate more often where common interpretations or limitations have occurred in hardware representations as is done, for example, at the bottom of page 42. There is some careful description of the mechanism of own dynamic arrays in chapter 9 , but there must be very few implementations of ALGOL 60 which provide any such facility. This is probably a result of the book being four years old.

In spite of these detailed criticisms, however, the description of the language is very good. Such facilities as Jensen's Device and Sneaky procedures rarely appear in books which are of this size. It is interesting to note that an earlier edition in 123 pages and priced at $30 \mathrm{~s}$. did not contain the $A L(x) L 60$ report as an appendix. In this form it received praise by another reviewer for the omission. My own view is that, for the sake of completeness, the extra pages and $5 s$. are worth while.

R. J. ORD-SMITh

\section{WHAT LOVE MEANS}

\section{The Idea of Love}

By Robert G. Hazo. (Concepts in Western Thought Series.) Pp. xvii +488 . (New York and London: Frederick A. Praeger, 1967.) 66s.

The Idea of Love is the most recent publication resulting from the continuing research efforts conducted by the Institute for Philosophical Research which surveys and interprets basic Western approaches to such concepts as freedom, happiness, law, progress and so on, covering a time span stretching from ancient Greece to the present day. The current effort is indeed laudable and offers the serious sophisticated reader a highly selective, structured and summarized account of the contributions of some of the most prominent secular philosophers, leaders in the field of religious thought, psychology and psychiatry. The contributions cited, of course, are limited to their written productions related to concepts of love.

Mr Hazo, early in the volume, offers a set of terms and definitions crucial to the organization of the vast amount of available material, and essential to an understanding of his thrust. Foremost among these terms are: (1) "tendency", defined as a bridge between awareness of something to be done and the doing of it; (2) "acquisitive desire" with an emphasis on getting or acquiring as a final aim (self-interest); (3) "benevolent desire" aimed at the good or satisfaction of the beloved, rather than the self, at times modified to include mutuality or sharing, with its emphasis on giving rather than getting as a final aim; (4) "sexual desire" as expressed in physical pleasures and satisfactions derived from direct genital contact; and (5) "desire for union" with its two tributaries of complementarity and similarity. Equipped with such guide. posts for illumination and insights, we explore the writing. of a host of scholars as they relate to agape (basically supernatural, or God's love for man and man's love for' God and his fellow men) and eros (natural love on the human sexual level). Among some of the issues explored is the question of applicability of physical expression between persons of the same sex, to the Western concapt of love. In this area, Plato's famous ladder of love is introduced, to illustrate his and other like minded ancient Greeks' convictions about the role of the older lover in introducing the younger beloved, also male, into the arts of love as a prelude to achieving a higher plateau of friendship and meaningful intellectual communication and communion between the partners. Except for the Greek school of philosophers and their more or less explicit followers, human or secular love is conceived as desire between man and woman. Direct contact between members of the same sex is treated as a deviation, abnormality, or at best an arrested personality development by the other quoted experts ranging from Aquinas, Augustine and Luther, to Freud, Fromm, Reik and Lewis.

The author allots considerable space to the contributions of several theologians, foremost among whom are: (1) St Thomas Aquinas with his core belief that God's love comes first, and from His love goodness, charity anci brotherhood are created; (2) Bernard of Clairvaux with his concern that the highest level of love is achieved when man loves God for His own sake and also himself for God's sake; (3) Nygen with his clarification of man's love for God as faith; and (4) St Augustine with his view that eternal salvation stems only from human love for God. Paul Tillich is included to demonstrate that not all theologians see the existence of a dichotomy between eros and agape-natural and divine love.

Reik, Fromm and Freud receive the bulk of space devoted to modern psychiatrists. Reik makes the point that sex is a biological need; love is not. Fromm suggests that love is a desire to escape loneliness, and the noed for a mature benevolent union is highlighted. As to be expected, Freud's schema to explain psycho-sexual development, by dividing the personality into the libido, id and ego, is included, as well as numerous references to his conceptualization of life and death instincts.

In a brief review, it is not possible to mention all the authors whom Hazo quotes and interprets in this text. Also one needs to read the volume carefully in order to delve into some of the numerous definitions of friendship, charity, fellowship, and love of neighbour scattered throughout.

In researching Western ideas of love, Hazo does noi here include the contributions made by playwrights, novelists and poets. He limits material to those philosophers, theologians and psychologists who, in his opinion, have made major and substantive theoretical contributions to the literature on love. Briefly, The Idea of Love is not a book to attempt to read or digest in a week-end. Rather it should be dipped into selectively, a little at a time. If read in one or two sittings, one would run the risk of blurring the major terms as defined and illustrated in the text. Thus, it is to be recommended as a reference book.
WILLIAM J. FRFEMAN 